\title{
Multi-System Inflammatory Syndrome in Children (MIS-C), Kawasaki Disease and Toxic Shock Syndrome so Different and Similar
}

\author{
Elda Skenderi, Admir Sulovari, Gjeorgjina Kuli-Lito, Nilsa Shahini, Griselda Toci, Ada Pema, \\ Blerta Imeri
}

University Hospital Center "Mother Tereza”, Tirana, Albania

Email: elda_skenderi@yahoo.com

How to cite this paper: Skenderi, E., Sulovari, A., Kuli-Lito, G., Shahini, N., Toci, G., Pema, A. and Imeri, B. (2021) Multi-System Inflammatory Syndrome in Children (MIS-C), Kawasaki Disease and Toxic Shock Syndrome so Different and Similar. Journal of Biosciences and Medicines, 9, 74-86. https://doi.org/10.4236/jbm.2021.99007

Received: August 2, 2021

Accepted: September 6, 2021

Published: September 9, 2021

Copyright $\odot 2021$ by author(s) and Scientific Research Publishing Inc. This work is licensed under the Creative Commons Attribution International License (CC BY 4.0).

http://creativecommons.org/licenses/by/4.0/

\begin{abstract}
Children are infected with Severe Acute Respiratory Syndrome Coronavirus 2 (SARS-CoV-2), but they are asymptomatic or suffer a mild disease compared to adults. However, the post-infectious immune dysregulation may result in the Multisystem Inflammatory Syndrome in Children (MIS-C). The most common presentations of MIS are fever, gastrointestinal (diarrhea, vomiting, abdominal pain), cardiovascular, mucocutaneous (rash, mucus membrane changes, conjunctival injection), respiratory (including sore throat), headache, limb and periorbital edema, and elevated inflammation markers. Some clinical and laboratory features of MIS-C are similar to other systemic diseases of childhood as Kawasaki disease and Toxic Shock Syndrome. Here are reported three cases in children with MIS-C, Kawasaki disease and Toxic Shock Syndrome to highlight the similarities and differences of these diseases.
\end{abstract}

\section{Keywords}

Multi-System Inflammatory Syndrome in Children (MIS-C), Kawasaki Disease, Toxic Shock Syndrome

\section{Introduction}

Severe Acute Respiratory Syndrome Coronavirus 2 (SARS-CoV-2) is the novel coronavirus causing COVID-19 disease in humans. It was first identified in an outbreak of respiratory illness cases in Wuhan City, China [1]. The virus spread soon all over the world and on March 11, 2020, the World Health Organization (WHO) declared COVID-19 a global pandemic [2]. By June 28, 2021, confirmed COVID-19 infections number over 180 million individuals worldwide and have 
resulted in over 3.9 million deaths [3]. COVID-19 ranges from asymptomatic, mild symptoms to severe illness and mortality. Symptoms may develop 2 days to 2 weeks after exposure to the virus. The principal mode by which people are infected with SARS-CoV-2 is through exposure to respiratory droplets carrying infectious viruses during coughing, sneezing, talking or contact with contaminated surfaces. The clinical presentation in adults ranges from mild illness to severe pneumonia, Acute Respiratory Distress Syndrome (ARDS), acute cardiac injury and thromboembolic complications. Patients with severe disease have evidence of hyper-immune response with persistent fevers, elevated inflammatory parameters and elevated inflammatory cytokines [4] [5]. In children, respiratory symptoms are the most common followed by fever and gastrointestinal symptoms [6]. Disease burden in children is difficult to determine because the proportion of asymptomatic infected children is high. The rate of children with critical illness ranges from $0.4 \%$ - $9 \%$ of confirmed cases, some reports include patients diagnosed in hospital [7] [8]. The differences between adults and children may be partly explained by the characteristics of the pediatric immune system. The immune system in children is highly prepared for novel pathogens, due to high levels of innate IgM antibodies and the ability to rapidly produce natural antibodies with broad reactivity [9]. Other explanations are alterations in $\mathrm{T}$ cell populations in adults due to continuous antigen stimulation and thymic involution, varied levels of ACE-2 expression in children and the simultaneous presence of other viruses in the respiratory mucosa of children, competing with SARS-CoV-2 [10]. Besides all these children have fewer comorbidities and a stronger pulmonary regenerative potential than adults [11].

Kawasaki Disease (KD) is an acute febrile illness of early childhood characterized by vasculitis of the medium-sized arteries. Its predilection for the coronary arteries, results in a potential for the development of Coronary Artery Aneurysms (CAAs) and thus sudden death. This is the reason, $\mathrm{KD}$ has become the leading cause of acquired heart disease in developed nations [12]. It was first described in 1967 by Dr. Tomisaku Kawasaki, in Japan [13]. KD is now recognized worldwide, although the greatest number of cases has been in Japan. Despite the prominent mucocutaneous clinical findings, $\mathrm{KD}$ is a generalized vasculitis that involves medium-sized arteries. Although the vascular inflammation is most pronounced in the coronary vessels, vasculitis can also occur in veins, capillaries, small arterioles, and larger arteries. In the earliest stages of the disease, the endothelial cells and the vascular media become edematous, then 7 - 9 days after the onset of fever, an influx of neutrophils occur, followed by a proliferation of $\mathrm{CD}^{+}$(cytotoxic) lymphocytes and immunoglobulin A-producing plasma cells. The inflammatory cells secrete various cytokines, interleukins that target the endothelial cells and result in a cascade of events that lead to fragmentation of the internal elastic lamina and vascular damage [14]. Over the next few weeks to months, the active inflammatory cells are replaced by fibroblasts and monocytes, and fibrous connective tissue, so the vessel wall becomes narrowed or occluded owing to stenosis or 
a thrombus [15] [16]. The etiology of KD remains unknown. There was suspected that the etiology of KD was infectious, but no single infectious agent has been implicated. Children present with fever, rash, conjunctival injection, cervical lymphadenopathy, inflammation of the lips and oral cavity, as well as erythema and edema of the hands and feet. There is found involvement of other organs, rather than mucocutaneous, such as the liver, lungs, gastrointestinal tract, central nervous system and joints. The overall clinical presentation of patients with KD is similar to that of patients with a viral or super-antigenic disease. However, investigations have shown that the immune response in $\mathrm{KD}$ is oligoclonal, which is seen as a response to a conventional antigen, rather than polyclonal, as would be found in a super-antigen-driven response [17] [18].

Toxic Shock Syndrome (TSS) is a multisystem disease manifested by sudden onset of fever, chills, hypotension, and rash. Multisystem involvement may cause vomiting, diarrhea, myalgia, mucous membrane hyperemia, mental confusion, renal dysfunction, hepatic abnormalities, and thrombocytopenia. TSS is caused by toxin-producing strains of staphylococci (staphylococcal TSS) and streptococci (streptococcal TSS). Staphylococcal toxic shock syndrome was first described in children in 1978 [19]. Staphylococcal Toxic Shock Syndrome (TSS) is caused by certain toxin-producing strains. Toxic Shock Syndrome Toxin-1 (TSST-1) and the enterotoxins are super-antigens. They result in nonspecific T-lymphocyte stimulation without normal antigenic recognition. This massive activation of lymphocytes leads to the release of cytokines that contribute to the development of toxic shock syndrome [20]. Streptococcal Toxic Shock Syndrome (STSS) is a serious complication caused by exotoxins of Group A Streptococcus (GAS). These toxins trigger a cascade of inflammatory cytokines, such as tumor necrosis factor-alpha, Interleukin (IL)-2, and IL-6, leading to multi-organ injury and shock. STSS presents with fulminant shock and rash, is rapidly progressive with Multi-Organ Dysfunction Syndrome [21]. The onset of STSS is usually abrupt. Symptoms include fever, chills, myalgia, malaise, headache, sore throat, muscle tenderness, fatigue, vomiting, watery diarrhea, and abdominal discomfort [22]. Streptococcal TSS is associated with poorer outcomes than staphylococcal TSS [23].

\section{Method \& Material}

This is a case-report series, presenting children with: Post COVID-19 MultiSystem Inflammatory Syndrome in Children (MIS-C), Kawasaki Disease and Toxic Shock Syndrome respectively. Children were admitted in the General Pediatric Ward at the University Hospital Center "Mother Teresa", Tirana, Albania during December 2020-April 2021.

\subsection{Case No. 1 Post COVID-19 Multi-System Inflammatory Syndrome in Children (MIS-C)}

An 8-years old boy admitted to the University Hospital Center of Tirana with a history of 5-days high and persistent fever, nausea, vomiting, abdominal pain 
and diarrhea. The day previous to admission he experienced a widespread rash and his general condition was getting worse. On medical history his parent revealed that their nasopharyngeal reverse transcription-polymerase chain reaction (RT-PCR) for COVID-19 were positive one month ago, the child did not take the test but suffered 2 days moderate fever without other symptoms.

On physical examination the child appeared ill, irritated with persistent high fever $39^{\circ} \mathrm{C}$ every 3 - 4 hours. There were observed palpable cervical lymph glands, red colored lips, a strawberry tongue, hyperemic tonsils, injected conjunctiva, and a wide spread poly-morph rash on the skin (Figure 1). The heart and the lungs appeared normal on examination, the abdomen was soft and palpable. The extremities were found slightly edematous.

RT-PCR for COVID-19 was negative and a positive serologic test for resent COVID-19 infection, COVID-19 IgG 117 AU/ml (0 - 1), COVID-19 IgM 0.652 COI $(0-1)$.

Laboratory investigations revealed a blood cell count of WBC 6300 cells $/ \mathrm{mm}^{3}$ (82.6\% neutrophils and $13.4 \%$ lymphocytes), RBC 4,140,000 cells $/ \mathrm{mm}^{3}$, Hemoglobin level $10.0 \mathrm{~g} / \mathrm{dL}$, Hematocrit value 30.1\%, normal Platelet count 190,000 cells $/ \mathrm{mm}^{3}$, Erythrocyte sedimentation rate $35 \mathrm{~mm} / \mathrm{h}(<15 \mathrm{~mm} / \mathrm{h})$, normal Aspartate aminotransferase 19U/L (14 - $35 \mathrm{U} / \mathrm{L})$, and Alanine aminotransferase 14 U/L ( 9 - $24 \mathrm{U} / \mathrm{L})$, Creatin kinase $76 \mathrm{U} / \mathrm{L}(30$ - $200 \mathrm{U} / \mathrm{L})$, normal Blood urea nitrogen $18.6 \mathrm{mg} / \mathrm{dL}(15-36 \mathrm{mg} / \mathrm{dL})$, and Creatinine $0.56 \mathrm{mg} / \mathrm{dL}(0.44-0.64$ $\mathrm{mg} / \mathrm{dL}$ ), Serum total protein $6.6 \mathrm{~g} / \mathrm{dL}(6-8 \mathrm{~g} / \mathrm{dL})$, Albumin $3.7 \mathrm{mg} / \mathrm{dL}$ ( 3.8 - 5.4 $\mathrm{mg} / \mathrm{dL})$, high $\mathrm{C}$ reactive protein $18.11 \mathrm{mg} / \mathrm{dL}(<0.5 \mathrm{mg} / \mathrm{dL})$, slightly elevated D-dimer $0.73 \mathrm{ug} / \mathrm{dL}(<0.5 \mathrm{ug} / \mathrm{dL})$, high Fibrinogen activity $580 \mathrm{mg} / \mathrm{dL}$ (140 - 360 $\mathrm{mg} / \mathrm{dL})$, PT quick time $88 \%$ (70\% - 110\%), Prothrombin time/international normalized ratio (INR) 1.09 (0.85 - 1.15), aPTT $33.5 \mathrm{sec}(24-35 \mathrm{sec})$, high Ferritin $369.94 \mathrm{ng} / \mathrm{mL}$ (13.7 - 79.8), Cholesterol $267 \mathrm{mg} / \mathrm{dL}(<170)$, Triglyceride 319 mg/dL (44 - 197), HDL Cholesterol $71 \mathrm{mg} / \mathrm{dL}$ (36 - 73), LDL Cholesterol 180 $\mathrm{mg} / \mathrm{dL}(<110)$, Interleukin $616.24 \mathrm{pg} / \mathrm{ml}(<7 \mathrm{pg} / \mathrm{ml})$.

Blood and urine cultures were negative. Radiologic examination of the lungs and heart were normal. Therapy consisted of intra-venous ceftriaxone, IVIG 2

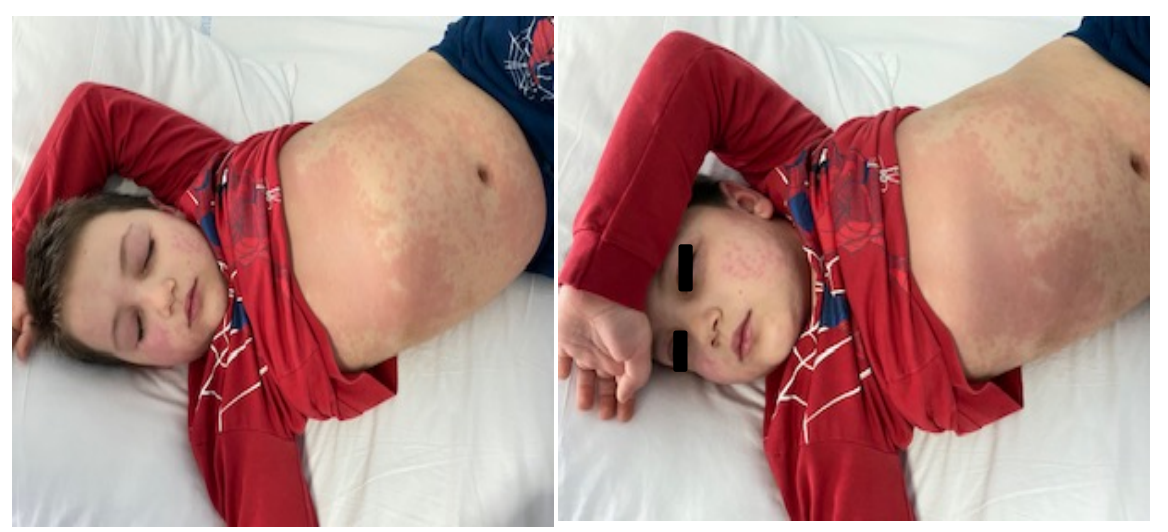

Figure 1. Post COVID-19 multi-system inflammatory syndrome in a child (MIS-C). 
$\mathrm{mg} / \mathrm{kg}$ mono-dose, and corticosteroids. Fever subsided in 2 days and the child was feeling well gradually.

After 1 week blood count revealed high WBC 40,100 cells $/ \mathrm{mm}^{3}$ (60.3\% neutrophils and $24.6 \%$ lymphocytes), RBC 3,910,000 cells $/ \mathrm{mm}^{3}$, Hemoglobin level $9.8 \mathrm{~g} / \mathrm{dL}$, Hematocrit value $29.3 \%$, high Platelet count 798,000 cells $/ \mathrm{mm}^{3}$, C reactive protein $1.64 \mathrm{mg} / \mathrm{dL}(<0.5 \mathrm{mg} / \mathrm{dL})$, slightly elevated D-dimer $0.94 \mathrm{ug} / \mathrm{dL}$ $(<0.5 \mathrm{ug} / \mathrm{dL})$, normal Fibrinogen activity $313 \mathrm{mg} / \mathrm{dL}(140-360 \mathrm{mg} / \mathrm{dL})$.

Therapy in discharge consisted in oral corticosteroids gradually tapered in 1 weeks and aspirin for 8 weeks.

After 4 weeks, all elevated parameters normalized except platelets, which lowered gradually and normalized in 8 weeks. Echography of the heart showed no dilatation of the coronary artery in the follow-up.

\subsection{Case No. 2 Kawasaki Disease}

A 20-months old boy (Figure 2) admitted to the University Hospital Center of Tirana with a history of a 5-days high fever and a wide spread rash. He had no family history with SARS CoV-2 infection. On physical examination he appeared

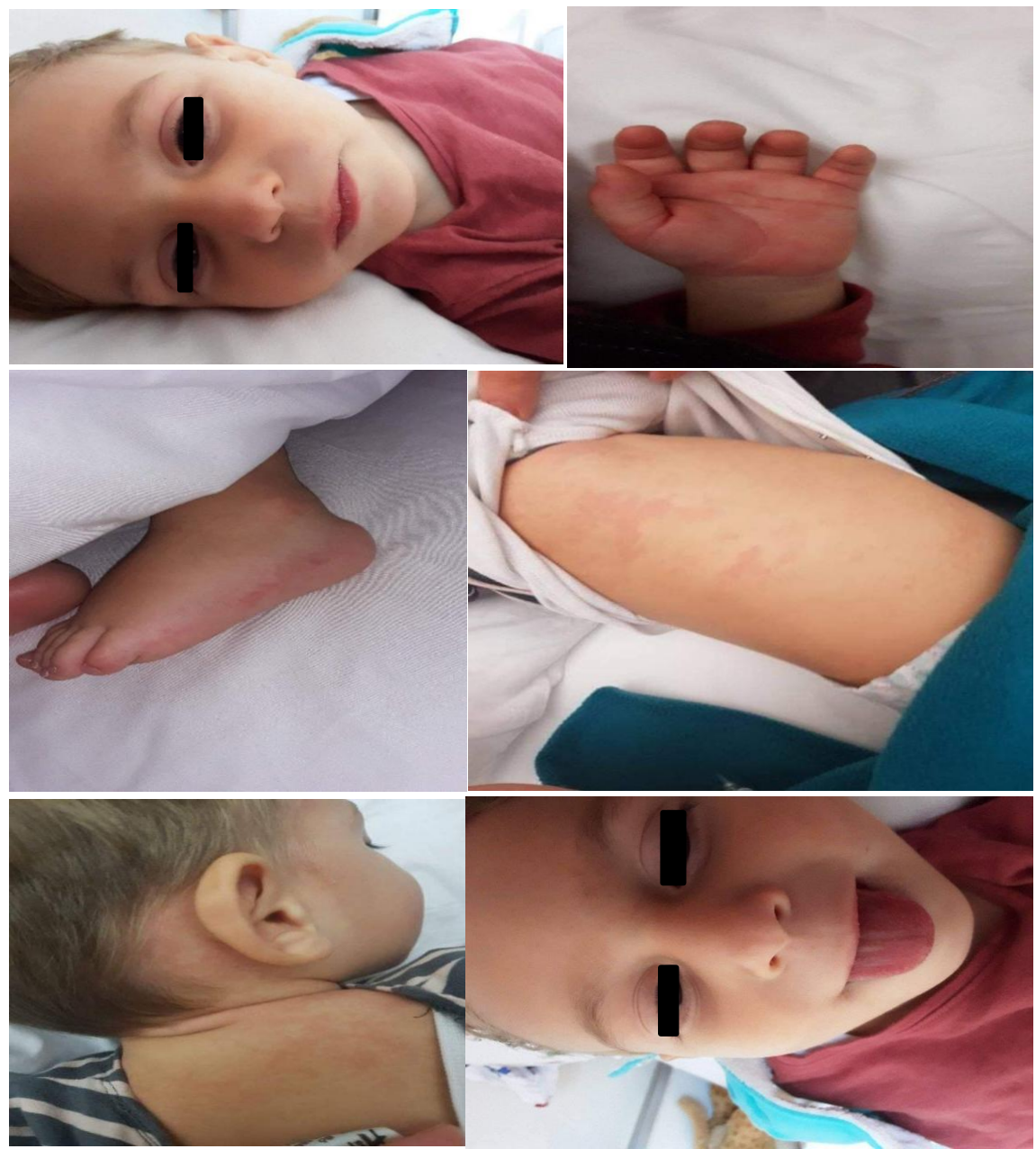

Figure 2. Child with Kawasaki Disease. 
ill, irritated, with high fever $39^{\circ} \mathrm{C}$ and poor feeding. There were observed bilateral palpable cervical lymphatic glands, red cracked lips, strawberry tongue, hyperemic tonsils, and injected sclera with palpebral edema. The rash was poly-morph and spread all over the body including palms and soles. The heart and lungs were normal in examination, abdomen was soft and palpable. There were observed edema of the hands and feet.

Tests for COVID-19 both pharyngeal RT-PCR and serology were negative. Laboratory investigations on admission revealed a blood cell count of high WBC 19,000 cells $/ \mathrm{mm}^{3}$ (69\% neutrophils and $24.1 \%$ lymphocytes), RBC 4,160,000 cells $/ \mathrm{mm}^{3}$, Hemoglobin level $11.3 \mathrm{~g} / \mathrm{dL}$, Hematocrit value 35.7\%, normal Platelet count 212,000 cells $/ \mathrm{mm}^{3}$, Erythrocyte sedimentation rate $28 \mathrm{~mm} / \mathrm{h}(<15 \mathrm{~mm} / \mathrm{h})$, normal Aspartate aminotransferase $35 \mathrm{U} / \mathrm{L}(14-35 \mathrm{U} / \mathrm{L})$, and Alanine aminotransferase $30 \mathrm{U} / \mathrm{L}$ ( 9 - $24 \mathrm{U} / \mathrm{L}$ ), Creatine kinase $75 \mathrm{U} / \mathrm{L}$ (30 - $200 \mathrm{U} / \mathrm{L})$, normal Blood urea nitrogen $24.9 \mathrm{mg} / \mathrm{dL}(15-36 \mathrm{mg} / \mathrm{dL})$, and Creatinine $0.43 \mathrm{mg} / \mathrm{dL}$ $(0.44-0.64 \mathrm{mg} / \mathrm{dL})$, low serum total protein $5.5 \mathrm{~g} / \mathrm{dL}(6-8 \mathrm{~g} / \mathrm{dL})$, low serum Albumin $2.8 \mathrm{mg} / \mathrm{dL}(3.2-4.5 \mathrm{mg} / \mathrm{dL})$, high C reactive protein $5.15 \mathrm{mg} / \mathrm{dL}(<0.5$ $\mathrm{mg} / \mathrm{dL}$ ), normal D-dimer $130 \mathrm{mg} / \mathrm{dL}(<198 \mathrm{mg} / \mathrm{dL}$ ), high Fibrinogen activity 564 $\mathrm{mg} / \mathrm{dL}(160$ - $390 \mathrm{mg} / \mathrm{dL})$, PT quick time 101\% (70\% - 110\%), Prothrombin time/international normalized ratio (INR) 0.86 (0.85 - 1.15), aPTT $25.7 \mathrm{sec}(24$ $35 \mathrm{sec}$ ), normal Ferritin $33.00 \mathrm{ng} / \mathrm{mL}$ (5.3 - 99.9). Blood and urine cultures were negative. Radiologic examination of the lungs and heart were normal.

Medication consisted of intravenous ceftriaxone, IVIG $2 \mathrm{mg} / \mathrm{kg}$ in one admission, oral aspirin. Fever, rash, edema and conjunctivitis persisted after the first dose of IVIG although there was an improvement in the general condition of the child, so after 72 hours the second dose of IVIG was administrated. Fever, rash and conjunctivitis resisted to the second dose of IVIG, so intravenous corticosteroids were initiated. Fever subsided on the second day, rash faded, conjunctivitis was no longer visible and the child was feeling well. Platelets peaked in the third week $1,750,000$ cells $/ \mathrm{mm}^{3}$ and a periungual desquamation of the toes was visible (Figure 3). Platelets normalized gradually in the following weeks, and the follow up of the coronary artery resulted normal.

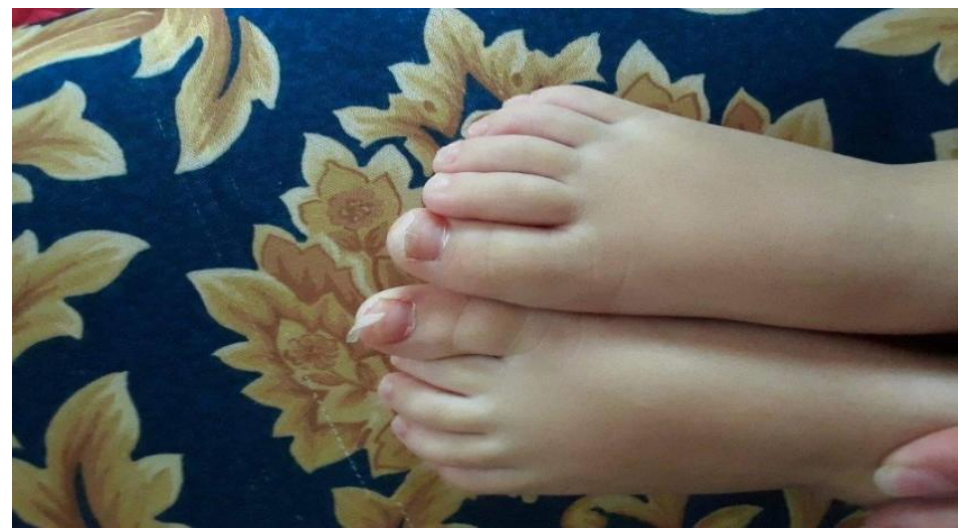

Figure 3. Periungual desquamation in Kawasaki Disease. 


\subsection{Case No. 3 Toxic Shock Syndrome in a Child}

A 3-years old boy presented at the University Hospital Center of Tirana with a history of sudden abdominal pain, vomiting and high fever. On physical examination he appeared ill, listless, with high fever $40^{\circ} \mathrm{C}$ and a generalized erythematous rash on the skin including face, trunk and extremities. There were observed red cracked lips, a strawberry tongue and hyperemic-hypertrophic tonsils. His conjunctivas were injected with slight bilateral palpebral edema and more evident edema on hands and feet. The child presented with hypotension. He had a heart rate of 146 beats/min, arterial pressure was low $90 \mathrm{~mm} / \mathrm{Hg}$ systolic pressure and $35 \mathrm{~mm} / \mathrm{Hg}$ diastolic pressure, peripheral pulses were weakly palpable. Respiratory rate was 40 breaths/min, oxygen saturation was $92 \%$. Abdomen was distend and painful in palpation.

The parents did not refer any family history with COVID-19 infection. RT-PCR and serology for COVID-19 were negative. Laboratory investigations on admission revealed a blood cell count of WBC 5600 cells $/ \mathrm{mm}^{3}(89.2 \%$ neutrophils and 3.6\% lymphocytes), RBC 4,380,000 cells $/ \mathrm{mm}^{3}$, Hemoglobin level $11.1 \mathrm{~g} / \mathrm{dL}$, Hematocrit value $34.5 \%$, Platelet count 143,000 cells $/ \mathrm{mm}^{3}$, normal Aspartate aminotransferase $36 \mathrm{U} / \mathrm{L}(21-44 \mathrm{U} / \mathrm{L})$, and Alanine aminotransferase $16 \mathrm{U} / \mathrm{L}(9-24 \mathrm{U} / \mathrm{L})$, Creatine kinase $154 \mathrm{U} / \mathrm{L}$ (30 - $200 \mathrm{U} / \mathrm{L})$, Blood urea nitrogen $37.1 \mathrm{mg} / \mathrm{dL}(15-36 \mathrm{mg} / \mathrm{dL})$, and Creatinine $0.55 \mathrm{mg} / \mathrm{dL}(0.38-0.54 \mathrm{mg} / \mathrm{dL})$, Serum total protein $5.5 \mathrm{~g} / \mathrm{dL}(6-8 \mathrm{~g} / \mathrm{dL})$, Albumin $3.1 \mathrm{mg} / \mathrm{dL}(3.2-4.5 \mathrm{mg} / \mathrm{dL})$, high $\mathrm{C}$ reactive protein $17.15 \mathrm{mg} / \mathrm{dL}(<0.5 \mathrm{mg} / \mathrm{dL})$, D-dimer $130 \mathrm{mg} / \mathrm{dL}(<198$ $\mathrm{mg} / \mathrm{dL})$, Fibrinogen activity $231 \mathrm{mg} / \mathrm{dL}(160-390 \mathrm{mg} / \mathrm{dL})$, PT quick time $69 \%$ (70\% - 110\%), Prothrombin time/international normalized ratio (INR) 1.28 (0.85 - 1.15), aPTT $34.4 \mathrm{sec}(24-35 \mathrm{sec})$. Blood and urine cultures were negative. Group A B-hemolytic Streptococcus was found in oropharyngeal secretion culture.

The child recovered quickly after appropriate intra-venous antibiotic and fluids resuscitation. Desquamation was observed on the lips in the second week (Figure 4).

\section{Discussion}

At the beginning of COVID-19 pandemic, it seemed that children were less infected or suffered a mild disease, but soon several highly endemic countries reported a high incidence of Multisystem Inflammatory Syndrome (MIS) in children attributed to SARS CoV-2 infection [24] [25]. Children presented with signs of hyper-inflammation and shock with features similar to Kawasaki Disease (KD) or toxic shock syndrome. The pathophysiology of MIS-C in children was described with COVID-19 infection triggering macrophage activation followed by helper T-cell activation, which in turn leads to massive cytokine release with B-cell and plasma cell activation and the production of antibodies, leading to immune dysregulation and a hyper-immune response [26]. Children with severe MIS-C present with a cytokine storm believed to be related to delayed interferon 


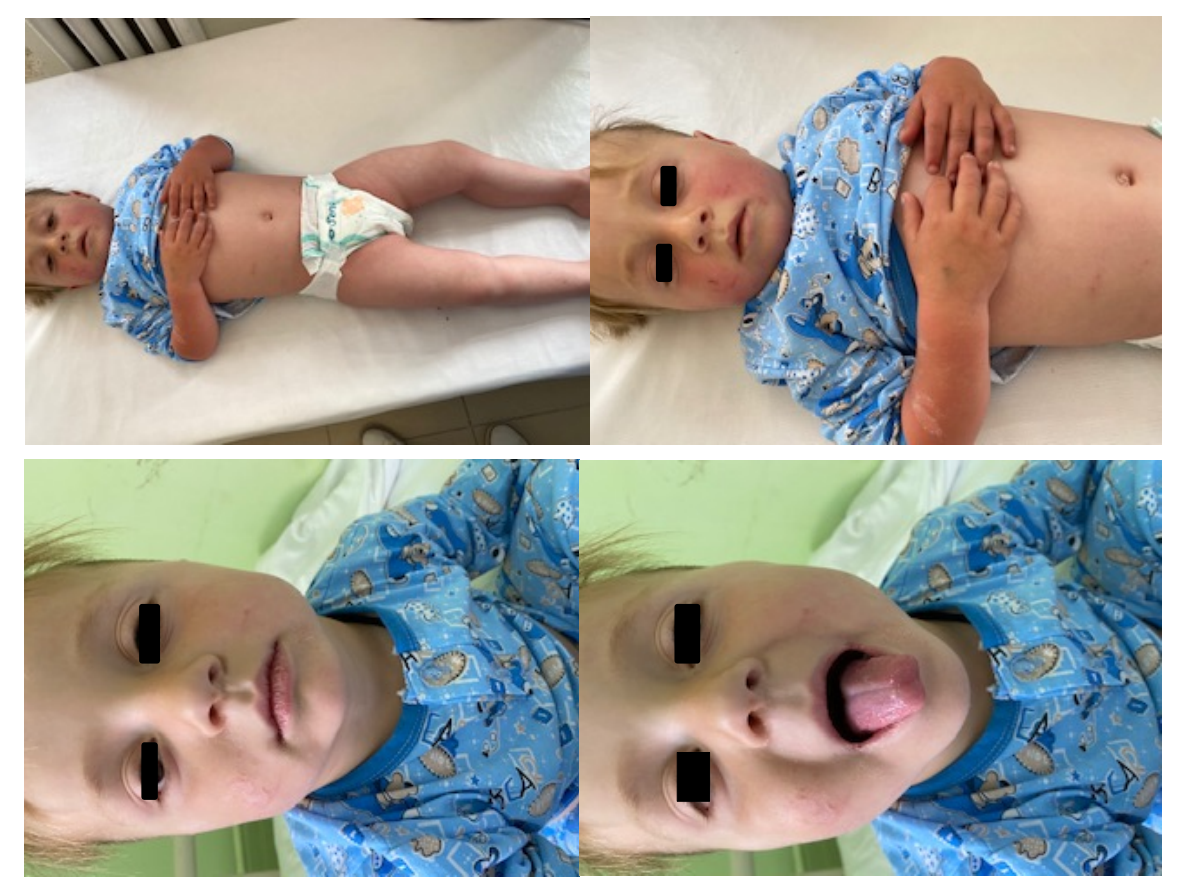

Figure 4. Erythematous rash in streptococcus toxic shock syndrome.

gamma responses and slow viral clearance, further leading to more pronounced inflammation [27]. They present with systemic signs of inflammation, often with significant cardiac, neurologic, and/or hematologic abnormalities (Table 1).

The evolution of this novel pathogen and the systemic effects it inflicts on children health are sometimes dramatic and unpredicted. This scenario has obliged the pediatrician to maintain a high index of suspicion while making a diagnosis. Considering this point of view the range of systemic diseases in children has been widened. The clinicians have already observed and confirmed the similarities and overlapping features between MIS-C, Kawasaki disease and Toxic Shock Syndrome.

In the first presented case, initially it was challenging to make a diagnosis. The child's age of 8-years old pointed more towards MIS-C than Kawasaki disease. All clinical features; polymorphous rash, conjunctival injection, red cracked lips, strawberry tongue, edema on hands and feet, persisted high fever, irritability were similar to Kawasaki disease. Inflammatory parameters like $\mathrm{C}$ reactive protein, ferritin, fibrinogen are increased in both diseases. In the presenting cases there were observed that white blood cells, neutrophils, $\mathrm{C}$ reactive protein, ferritin, fibrinogen, D-dimer were more elevated in MIS-C than in Kawasaki disease which is an exception to the general definition of both diseases (Table 2). According to CDC definition of MIS-C, leucopenia associated with lymphopenia (absolute lymphocyte count $<1000$ cells $/ \mathrm{mm}^{3}$ ) and thrombocytopenia are the most common hematological abnormalities. Lymphopenia may occur in individuals with COVID-19 when SARS-CoV-2 infects and kills T lymphocyte cells. However there was found a different scenario of the hematological findings in the child diagnosed with MIS-C, making challenging the differential diagnosis 
Table 1. CDC case definition for Multisystem Inflammatory Syndrome in Children (MIS-C) [25].

1) An individual aged $<21$ years with the following criteria

2) Clinical criteria

_ A minimum 24-h history of subjective or objective fever _ $38.0^{\circ} \mathrm{C}$ AND

_ Severe illness necessitating hospitalization AND

_ Two or more organ systems affected (i.e., cardiac, renal, respiratory, hematologic, gastrointestinal, dermatologic, neurological)

3) Laboratory evidence of inflammation

_ One or more of the following: an elevated CRP, ESR, fibrinogen, procalcitonin, D-dimer, ferritin, LDH, or IL-6; elevated neutrophils or reduced; low albumin

4) Laboratory or epidemiologic evidence of SARS-CoV-2 infection

_ Positive SARS-CoV-2 testing by RT-PCR, serology, or antigen OR

_ COVID-19 exposure within 4 weeks prior to onset of symptoms

5) No alternative diagnosis

Abbreviations: CDC, Centers for Disease Control; CRP, C-reactive protein; ESR, erythrocyte sedimentation rate; LDH, lactate dehydrogenase; RT-PCR, reverse transcriptase polymerase chain reaction; SARS-CoV-2, severe acute respiratory syndrome coronavirus- 2

Table 2. Comparison of clinical and laboratory features of MIS-C, Kawasaki disease, TSS.

\begin{tabular}{|c|c|c|c|}
\hline & MIS-C & Kawasaki disease & Toxic Shock Syndrome \\
\hline Child age & 8 years & 20 months & 3 years \\
\hline Fever & + & + & + \\
\hline Hypotension & - & - & + \\
\hline Mucous membrane involvement & + & + & + \\
\hline Rash & + & + & + \\
\hline Desquamation & - & + & + \\
\hline \multicolumn{4}{|l|}{ Altered mental status } \\
\hline Gastro-intestinal symptoms & + & - & + \\
\hline Respiratory distress & - & - & + \\
\hline WBC & 40,100 & 19,000 & 5600 \\
\hline PLT & 798,000 & $1,750,000$ & 143,000 \\
\hline CRP & $\uparrow \uparrow$ & $\uparrow$ & $\uparrow \uparrow$ \\
\hline Fibrinogen & $\uparrow$ & $\uparrow$ & $\mathrm{N}$ \\
\hline D-dimer & $\uparrow$ & $\uparrow$ & $\mathrm{N}$ \\
\hline Ferritin & $\uparrow$ & $\mathrm{N}$ & $\mathrm{N}$ \\
\hline Creatinine & $\mathrm{N}$ & $\mathrm{N}$ & $\uparrow$ \\
\hline Hyperlipidemia & + & - & - \\
\hline
\end{tabular}

with Kawasaki disease. In the presenting case a strikingly high of white blood cells $\left(40,100\right.$ cells $\left./ \mathrm{mm}^{3}\right)$ predominated by neutrophils and thrombocytosis $(798,000$ cells $/ \mathrm{mm}^{3}$ ) were found in the second week of the disease. The excessive inflammation induces an increased release of cytokines resulting in stimulation of 
bone-marrow, is a logical explanation in this case. These reactions are usually reactive and transient, particularly common during recovery phase of an infection or inflammation and subside when the primary stimulus ceases. Also it is generally accepted that SARS-CoV-2 acts as a super-antigen leading to hyperimmune response with persistent fevers, elevated inflammatory parameters and elevated inflammatory cytokines [4]. The clinical presentation of patients with $\mathrm{KD}$ is similar to that of patients with a viral or super-antigenic disease but investigations have shown that the immune response in $\mathrm{KD}$ is oligoclonal, which is seen as a response to a conventional antigen, rather than polyclonal, as would be found in a superantigen-driven response [17]. This may be a reasonable explanation of the differences in inflammatory and hematological markers. Although the child with MIS-C was quite critically ill, the use of IVIG administrated in the same manner as in Kawasaki disease, resulted life-saving. The use of IVIG is recommended in all patients who meet or do not meet Kawasaki disease criteria for possible beneficial immunomodulatory effects. The child recovered immediately after taking IVIG.

The child with Kawasaki disease was younger (20-months old) compared to the child with MIS-C (8 years old). In the medical history he had not gastrointestinal symptoms as the child with MIS-C, who had vomiting, abdominal pain and diarrhea. He had lower inflammatory parameters; white blood cells, $\mathrm{C}$ reactive protein, ferritin, fibrinogen, $\mathrm{D}$-dimer. He had strikingly high platelets $(1,750,000$ cells $/ \mathrm{mm}^{3}$ ) in the 2 - 3 week of the disease. Despite the prominent muco-cutaneous clinical findings, $\mathrm{KD}$ is a generalized vasculitis and thrombocytosis is a more prominent feature. Reactive thrombocytosis is usually mediated by increased release of numerous cytokines in response to infections, inflammation, vasculitis, tissue trauma. Thrombopoietin is the primary cytokine for platelet production and maturation. Other cytokines as interleukin-6, IL-3, IL-11, granulocyte macrophage colony-stimulating factor and erythropoietin participate in the stimulation of platelet production [28]. Despite the strikingly high platelet count thrombotic or hemorrhagic complication are high exceptional. Although IVIG had good effect on the child with MIS-C, the child with Kawasaki disease was resistant to two consequential doses of IVIG. The mechanisms of IVIG in Kawasaki disease is unclear and may include immunomodulatory effects on T regulatory cells [17]. Recovery after Kawasaki disease was more gradual than in MIS-C.

The onset of symptoms in Toxic Shock Syndrome (TSS) was more sudden and progressed rapidly than in MIS-C and Kawasaki disease. The child with TSS had a sudden onset of gastro-intestinal symptoms (vomiting, abdominal pain), high fever, and somnolence. When he arrived in the hospital, after a few hours, he was becoming hypotensive, oligo-uric and a generalized erythematous rash appeared and the child was listless. Whereas in children with MIS-C and Kawasaki disease the symptoms began more gradually in $3-5$ days they presented in the hospital. The acute phase reactants as $\mathrm{C}$ reactive protein and neutrophils are more quickly and highly elevated in TSS. In the case of TSS, streptococcus exotoxins act as super-antigens stimulating $\mathrm{T}$-cell responses through their ability to 
bind to both the Class II Major Histocompatibility Complex of antigen-presenting cells and T-cell receptors. This mechanism bypasses the classical antigen-processing procedures and results in excessive $\mathrm{T}$-cell proliferation. The conventional antigens activate only about $0.01 \%-0.1 \%$ of the $\mathrm{T}$-cell population whereas the super-antigens set in motion $5 \%-30 \%$ of the entire T-cell population. The net effect is massive production of cytokines that are capable of mediating shock and tissue injury [23]. As the symptoms in TSS began and progressed rapidly, so was the recovery after appropriate antibiotics and fluids resuscitation.

\section{Conclusion}

Children are infected with SARS-CoV-2, but they suffer a less severe acute infection compared to adults. The immune dysregulation inflicted by the virus has caused a delayed Multisystem Inflammatory Syndrome in Children (MIS-C), which may be life-threatening. The ultimate data of MIS-C have highlighted similarities between other well-defined syndromes including Kawasaki disease and Toxic Shock Syndrome. The increased prevalence of MIS-C and the overlapping signs and symptoms with these systemic diseases of childhood make the appropriate diagnosis become challenging.

\section{Acknowledgements}

We thank all the medical staff of the General Pediatric Ward for their constant support.

\section{Conflicts of Interest}

The authors declare no conflicts of interest regarding the publication of this paper.

\section{References}

[1] CDC (2019) Novel Coronavirus, Wuhan, China. https://www.cdc.gov/coronavirus/2019-ncov/about/index.html

[2] Gallegos, A. (2020) WHO Declares Public Health Emergency for Novel Coronavirus. Medscape Medical News. https://www.medscape.com/viewarticle/924596

[3] WHO Coronavirus Disease (COVID-19) Dashboard. World Health Organization. https://covid19.who.int

[4] Huang, C., Wang, Y., Li, X., Ren, L., Zhao, J., Hu, Y., et al. (2020) Clinical Features of Patients Infected with 2019 Novel Coronavirus in Wuhan, China. The Lancet, 395, 497-506. https://doi.org/10.1016/S0140-6736(20)30183-5

[5] Mehta, P., McAuley, D.F., Brown, M., Sanchez, E., Tattersall, R.S. and Manson, J.J. (2020) COVID-19: Consider Cytokine Storm Syndromes and Immunosuppression. The Lancet, 395, 1033-1034. https://doi.org/10.1016/S0140-6736(20)30628-0 https://www.ncbi.nlm.nih.gov/pmc/articles/PMC7270045

[6] Bialek, S., Gierke, R., Hughes, M., McNamara, L.A., Pilishvili, T. and Skoff, T. (2020) Coronavirus Disease 2019 in Children-United States, February 12-April 2, 2020. Morbidity and Mortality Weekly Report, 69, 422-426. https://doi.org/10.15585/mmwr.mm6914e4 
[7] Parri, N., Lenge, M. and Buonsenso, D. (2020) Children with COVID-19 in Pediatric Emergency Departments in Italy. The New England Journal of Medicine, 383, 187-190. https://doi.org/10.1056/NEJMc2007617

[8] Götzinger, F., Santiago-garcía, B., Noguera-julián, A., Lanaspa, M., Lancella, L. and Carducci, F.I.C. (2020) COVID-19 in Children and Adolescents in Europe: A Multinational, Multicentre Cohort Study. The Lancet Child \& Adolescent Health, 4, 653-661. https://doi.org/10.1016/S2352-4642(20)30177-2

[9] Carsetti, R., Quintarelli, C., Quinti, I., Piano Mortari, E., Zumla, A., Ippolito, G., et al. (2020) The Immune System of Children: The Key to Understanding SARS-CoV-2 Susceptibility? The Lancet Child \& Adolescent Health, 4, 414-416. https://doi.org/10.1016/S2352-4642(20)30135-8

[10] Yuki, K., Fujiogi, M. and Koutsogiannaki, S. (2020) COVID-19 Pathophysiology: A Review. Clinical Immunology, 215, Article ID: 108427.

https://doi.org/10.1016/j.clim.2020.108427

[11] Dhochak, N., Singhal, T., Kabra, S.K., Lodha, R. (2020) Pathophysiology of COVID-19: Why Children Fare Better than Adults? Indian Journal of Pediatrics, 87, 537-546. https://doi.org/10.1007/s12098-020-03322-y

[12] McCrindle, B.W., Rowley, A.H., Newburger, J.W., et al. (2017) Diagnosis, Treatment, and Long-Term Management of Kawasaki Disease: A Scientific Statement for Health Professionals from the American Heart Association. Circulation, 135, e927-e999.

[13] Kawasaki, T. (1967) Acute Febrile Mucocutaneous Syndrome with Lymphoid Involvement with Specific Desquamation of the Fingers and Toes in Children. Arerugi, 16, 178-222.

[14] Rowley, A.H. and Shulman, S.T. (2010) Pathogenesis and Management of Kawasaki Disease. Expert Review of Anti-Infective Therapy, 8, 197-203.

https://doi.org/10.1586/eri.09.109

[15] Burns, J.C., Shimizu, C., Shike, H., Newburger, J.W., Sundel, R.P., Baker, A.L., et al. (2005) Family-Based Association Analysis Implicates IL-4 in Susceptibility to Kawasaki Disease. Genes \& Immunity, 6, 438-444. https://doi.org/10.1038/sj.gene.6364225

[16] Wang, C.L., Wu, Y.T., Liu, C.A., Kuo, H.C. and Yang, K.D. (2005) Kawasaki Disease: Infection, Immunity and Genetics. The Pediatric Infectious Disease Journal, 24, 998-1004. https://doi.org/10.1097/01.inf.0000183786.70519.fa

[17] Melish, M.E. and Hicks, R.V. (1990) Kawasaki Syndrome: Clinical Features. Pathophysiology, Etiology and Therapy. Journal of Rheumatology Supplement, 24, 2-10.

[18] Leung, D.Y., Meissner, H.C., Fulton, D.R., Murray, D.L., Kotzin, B.L. and Schlievert, P.M. (1993) Toxic Shock Syndrome Toxin-Secreting Staphylococcus aureus in Kawasaki Syndrome. The Lancet, 342, 1385-1388. https://doi.org/10.1016/0140-6736(93)92752-F

[19] Todd, J., Fishaut, M., Kapral, F. and Welch, T. (1978) Toxic-Shock Syndrome Associated with Phage-Group-I Staphylococci. The Lancet, 2, 1116-1118. https://doi.org/10.1016/S0140-6736(78)92274-2

[20] Davis, J.P., Chesney, P.J. and Wand, P.J. (1980) Toxic-Shock Syndrome: Epidemiologic Features, Recurrence, Risk Factors, and Prevention. The New England Journal of Medicine, 303, 1429-1435. https://doi.org/10.1056/NEJM198012183032501

[21] Stevens, D.L., Tanner, M.H. and Winship, J. (1989) Severe Group A Streptococcal Infections Associated with a Toxic Shock-Like Syndrome and Scarlet Fever Toxin A. The New England Journal of Medicine, 321, 1-7. https://doi.org/10.1056/NEJM198907063210101

[22] Davies, H.D., McGeer, A. and Schwartz, B. (1996) Invasive Group A Streptococcal 
Infections in Ontario, Canada. Ontario Group A Streptococcal Study Group. The New England Journal of Medicine, 335, 547-554. https://doi.org/10.1056/NEJM199608223350803

[23] Norrby-Teglund, A., Muller, M.P. and Mcgeer, A. (2005) Successful Management of Severe Group A Streptococcal Soft Tissue Infections Using an Aggressive Medical Regimen Including Intravenous Polyspecific Immunoglobulin Together with a Conservative Surgical Approach. Scandinavian Journal of Infectious Diseases, 37, 166-172. https://doi.org/10.1080/00365540410020866

[24] Viner, R.M., Mytton, O.T., Bonell, C., et al. (2020) Susceptibility to SARS-CoV-2 Infection among Children and Adolescents Compared with Adults: A Systematic Review and Meta-Analysis. JAMA Pediatrics, 175, 143-156.

https://doi.org/10.1001/jamapediatrics.2020.4573

[25] AAP (2020) Children and COVID-19: State Data Report. American Academy of Pediatrics.

https://downloads.aap.org/AAP/PDF/AAP\%20and\%20CHA\%20-\%20Children\%20a nd\%20COVID-19\%20State\%20Data\%20Report\%2010.1.20\%20FINAL.pdf

[26] Nakra, N.A., Blumberg, D.A., Herrera-Guerra, A. and Lakshminrusimha, S. (2020) Multi-System Inflammatory Syndrome in Children (MIS-C) Following SARS-CoV-2 Infection: Review of Clinical Presentation, Hypothetical Pathogenesis, and Proposed Management. Children (Basel), 7, 69. https://doi.org/10.3390/children7070069

[27] Rowley, A.H. (2020) Understanding SARS-CoV-2-Related Multisystem Inflammatory Syndrome in Children. Nature Reviews Immunology, 20, 453-454. https://doi.org/10.1038/s41577-020-0367-5

[28] Zheng, S.Y., Xiao, Q.Y., Xie, X.H., et al. (2016) Association between Secondary Thrombocytosis and Viral Respiratory Tract Infections in Children. Scientific Reports, 6, Article No. 22964. https://doi.org/10.1038/srep22964 